Przegląd Badań Edukacyjnych Educational Studies Review

ISSN 1895-4308

nr 19 (2/2014), s. 149-166

METAANALIZY

BADAŃ

EDUKACYJNYCH

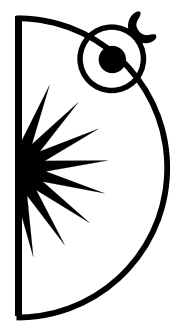

Elżbieta Wieczór

Uniwersytet Mikołaja Kopernika w Toruniu, e-mail: ewieczor@umk.pl

\title{
Określanie ram jakości w zakresie wczesnej opieki i edukacji
}

DOI: http://dx.doi.org/10.12775/PBE.2014.026

\section{Specifying Quality Framework for Early Care and Education}

\begin{abstract}
The article concerns the issue of early care, upbringing and education of children. They is important and timeless subjects in the context of social, demographic and educational changes. Basing on literature and research reports, the article analyses systems of early care and education in Poland and around the world. Early childhood education was recognised as priority, the emphasis was placed on high quality care and education, which requires provision of financial resources, skilled workforce, good quality programs. This involves, above all, change in thinking of services for the age group of $0-3$ years. A systemic integrated approach to the care and education of the youngest children is the determinant of quality; care, upbringing and education must be seen as a whole to provide the highest quality of service.
\end{abstract}

Key words: child, (early) care, upbringing and education, nursery, kindergarten, guardian, parents, quality, standards

\section{Wczesna opieka i edukacja}

Wczesną opiekę i edukację rozumiemy jako kompleksowe oddziaływanie opiekuńczo-wychowawczo-edukacyjne, obejmujące dzieci w wieku 0-6 lat, tj. w okresie żłobkowym i przedszkolnym. W wielu krajach od kilku już lat obserwujemy większe zainteresownie problematyką wczesnej opieki i eduka- 
cji, określanej jako kluczowej dla dalszej edukacji i całożyciowego rozwoju człowieka. „Został otwarty nowy etap współpracy unijnej w zakresie edukacji. Po raz pierwszy Unia Europejska podjęła problematykę oferty edukacyjnej dla dzieci od urodzenia do rozpoczęcia obowiązku szkolnego [...]. Wczesna edukacja została uznana za priorytet, nacisk został położony na komfort życia dziecka związany z zagwarantowaniem mu prawa do dobrej jakości opieki i edukacji, a to wymaga zapewnienia środków finansowych, wykwalifikowanej kadry, dobrej jakości programów. Wiąże się to więc przede wszystkim ze zmianą sposobu myślenia o usługach dla grupy wiekowej 0-3, w szczególności, gdy uda się to połączyć z unijnymi programami edukacji, a nie tylko koncentrowaniem się na promocji zatrudnienia dla matek małych dzieci. Poprzednie inicjatywy UE eksponowały działania wspierające rodziców pracujących zawodowo w udostępnianiu miejsc w placówkach opieki i edukacji” (Żytko, 2012, s. 21-22). Cieszy fakt, że w priorytetach działań edukacyjno-wychowawczych znajduje się praca z dziećmi poniżej 3 roku życia, choć jak ocenia M. Żytko: „o jakości opieki i edukacji w rozwoju dzieci do 3 roku życia znacznie mniej mówi się nadal niż o rozwoju powyżej 3 roku życia" (tamże, s. 24). Komisja Europejska określa wczesną opiekę i edukację jako jedno z działań priorytetowych na kilka najbliższych lat. Traktowana jest jako filar dalszego rozwoju i edukacji w kontekście całożyciowego, permanentnego rozwoju. Podkreśla się jednocześnie wysoką jakość wczesnej edukacji i opieki oraz jej korzyści. W lutym $2011 \mathrm{r}$. Komisja Europejska opublikowała swój pierwszy komunikat na temat wczesnej edukacji i opieki nad dzieckiem, w którym czytamy, że „wczesna edukacja i opieka nad dzieckiem (Early Childhood Education and Care) jest fundamentem umożliwiającym pomyślny przebieg uczenia się przez całe życie, jest czynnikiem zwiększającym szanse na zatrudnienie. Najwcześniejsze doświadczenia dzieci tworzą podstawy dla wszystkich kolejnych etapów uczenia się. Jeżeli w pierwszych latach położy się solidne fundamenty, to dalsze uczenie się jest skuteczniejsze i istnieje większe prawdopodobieństwo, że będzie kontynuowane przez całe życie. Korzyści z wysokiej jakości wczesnej edukacji i opieki nad dzieckiem są wielorakie: społeczne, ekonomiczne i edukacyjne" (Komunikat Komisji Europejskiej, 2011, Bruksela.)

\section{Dzieci ze środowisk zaniedbanych społecznie i ekonomicznie}

Wczesna edukacja i opieka nad dzieckiem przynosi szczególnie dużo korzyści osobom znajdującym się $\mathrm{w}$ trudnej sytuacji, zwłaszcza tym pochodzącym ze środowisk migracyjnych i o niskich dochodach. Może pomóc przezwyciężyć 
biedę i dysfunkcje w rodzinach. Badania naukowe pokazują, że słabe wyniki w nauce są najsilniej skorelowane z ubóstwem i dysfunkcjami rodziny. Duże różnice w rozwoju obserwuje się już u trzylatków, a do 5 roku życia, jeśli nie są podjęte ukierunkowane działania zaradcze, te różnice jeszcze się pogłębiają. Badania w USA w placówkach dla najmłodszych dzieci pokazuja, że korzyści z ECEC odnoszone przez dzieci z ubogich rodzin są dwa razy większe od korzyści odnoszonych przez dzieci z lepiej usytuowanych środowisk. Wczesna edukacja i opieka są ważnymi czynnikami ograniczenia częstotliwości przedwczesnego kończenia nauki. Powszechny dostęp do wysokiej jakości wczesnej opieki i edukacji może zmniejszyć różnice w rozwoju społecznym oraz w poziomie umiejętności liczenia, czytania i pisania dzieci z różnych środowisk, może przerwać proces często prowadzący do słabych wyników w nauce i słabego zaangażowania w uczenie się, do przerwania kształcenia, a w konsekwencji do dziedziczenia biedy (Komunikat Komisji Europejskiej, 2011, Bruksela). Najwyższy zwrot z inwestycji we wczesną edukację otrzymuje się szczególnie od dzieci ze środowisk znajdujących się w niekorzystnej sytuacji społecznej (tamże). Do tej pory celem większości działań na poziomie UE było zwiększenie liczby miejsc w żłobkach i przedszkolach, aby umożliwić, szczególnie matkom, wejście na rynek pracy. W 2009 r. ministrowie edukacji ustanowili próg upowszechnienia wychowania przedszkolnego w Europie - do roku 2020 systemem wczesnej edukacji i opieki powinno zostać objęte co najmniej 95\% dzieci w wieku od 4 lat do czasu rozpoczęcia obowiązku szkolnego. Dużą wagę należy przykładać do zagwarantowania dobrej jakości wczesnej edukacji i opieki. Korzyści z wysokiej jakości wczesnej edukacji i opieki nad dzieckiem narastają z upływem czasu. Priorytetem strategicznych ram współpracy w dziedzinie kształcenia i szkolenia jest ,promowanie powszechnego, równego dostępu, podnoszenie jakości oferty i zwiększanie wsparcia dla nauczycieli edukacji przedszkolnej” (tamże).

\section{Opieka czy edukacja?}

Pytania, jakie nasuwają się najczęściej w odniesieniu do pracy z małymi dziećmi, dotyczą priorytetu działań - opieki czy edukacji. Co powinno być najistotniejsze, opieka czy edukacja, a może należy ujmować je łącznie? „W wielu częściach Świata mniejszości toczy się dyskusja na temat związku między opieką i edukacją w obszarze usług dla małych dzieci. Czy usługi te powinny ograniczać się do jednej z tych funkcji?" (Dahlberg, Moss, Pence, 2013, s. 150). Drugie istotne pytanie odnosi się do jakości w obszarze wczesnej edukacji i opieki. 
Jest to pytanie o „ważność wczesnego dzieciństwa - Jak mierzymy jakość? Jakie programy są najbardziej opłacalne? Jakich standardów potrzebujemy? Jak najlepiej osiagnnać pożądane rezultaty? Co działa?" (tamże, s. 44.) Pojawia się także pytanie, jak rozumiemy instytucje wczesnej edukacji? Odpowiedzi poszukujemy na podstawie obserwacji i analizy wielu obszarów wychowania żłobkowego i przedszkolnego.

\section{Zintegrowane, systemowe podejście do wczesnej opieki i edukacji}

W odniesieniu do wczesnej opieki i edukacji dzieci przyjmuje się dziś systemowe, zintegrowane, holistyczne podejście. W pełni zintegrowany system wczesnej opieki i edukacji to: brak podziału na opiekę żłobkową i przedszkolna, brak podziału na opiekunów żłobka i wychowawców przedszkoli, przejęcie usług w kompetencji jednego ministerstwa, powszechność i równość dostępu, wysoko wykwalifikowana i dobrze opłacana kadra, a w perspektywie niższy poziom ubóstwa wśród dzieci. „Systemowe podejście do usług wczesnej edukacji i opieki wymaga ścisłej współpracy między sektorami polityki, takimi jak edukacja, zatrudnienie, zdrowie i polityka społeczna”. W Raporcie ECEC (Early Childhood Education and Care) projektu dotyczącego włączania najmłodszych dzieci do systemu analizowanego przez Fundację Rozwoju Dzieci im. J. A. Komeńskiego, czytamy na temat zintegrowanego systemu opieki i edukacji dla małych dzieci i ich rodzin. W programie Working for Inclusion integrację zdefiniowano jako ,utworzenie jednolitego systemu z jednym ministerstwem odpowiedzialnym za całość oferty oraz jednolitymi ramami prawnymi dotyczącymi dostępu, finansowania, funkcjonowania i zatrudnienia" (Raport, 2011).

\section{Jakość wczesnej opieki i edukacji}

Równolegle z pytaniem o miejsce wczesnej opieki i edukacji, pojawia się pytanie o jakość usług. Czym jest jakość w życiu małych dzieci, po co i jak można ją definiować? „W minionych czasach jakość postrzegano raczej jako luksus niż konieczność [...], (dzisiaj) jakość ma znaczenie, i to znaczenie ogromne" (Kagan, Cohen, 1996, s. 2). Pojęcie jakości ewoluowało za sprawą zmian kulturowych, edukacyjnych. „Przeszliśmy długą drogę w refleksji nad problemem jakości [...]. Nie można analizować jakości bez analizy wczesnego dzieciństwa $\mathrm{i}$ instytucji dla małych dzieci, a te kwestie z kolei trzeba podjać w kontekście analizy czasów, w których żyjemy" (Dahlberg, Moss, Pence, 2013, s. 52). Analiza wczesnego dzieciństwa wpisuje się w dyskurs społeczny, otwartą debatę na 
temat poziomu usług. „Instytucje dla małych dzieci jako fora w społeczeństwie obywatelskim stwarzają okazję do konstruowania nowego dyskursu publicznego dotyczącego wczesnego dzieciństwa, co stanowi istotny wymiar «polityki dzieciństwa»” (tamże, s. 140). Dyskurs ten cechuje „różnorodność, złożoność, subiektywność i wielość perspektyw, ponowoczesność nadawania znaczenia. W obszarze wczesnego dzieciństwa dyskurs nadawania znaczenia odnosi się przede wszystkim do konstruowania i pogłębiania rozumienia instytucji dla małych dzieci i podejmowanych przez nie działań, a w szczególności pracy pedagogicznej - aby zrozumieć, co się dzieje" (tamże, 2013, s. 175). W obszarze jakości doszukać się można kilka dyskursów, jednym z nich jest ujmowanie jakości w kategoriach doskonałości, której istotą jest procesualność. „W praktyce ten dyskurs oznacza stały, niekończący się proces aktualizacji lub urzeczywistniania wartości uznanych za autoteliczne. Jakość nie jest tutaj czymś danym, lecz czymś zadanym [...], dyskurs ten ma postać dyskursu milczącego, a w wielu krajach jest podstawowym dyskursem praktyki edukacyjnej" (Mizerek, 2012, s. 19).

Martin Woodhead zauważa, że instytucje i programy opieki i edukacji dla małych dzieci mają do spełnienia ważną funkcję ,promotora zachowań demokratycznych, a dyskusje i negocjacje na temat ich jakości mogą być jednym ze środków do rozwoju państwa obywatelskiego" (Woodhead, 1998; wprowadzenie do wyd. pol. M. Karwowskiej-Struczyk, s. 7). Autor proponuje bardziej kontekstowe, holistyczne podejście do zagadnień jakości. „Odpowiednia opieka nad dziećmi nie jest już tylko sprawą tradycji przekazywanej z pokolenia na pokolenie przez dawanie przykładu i dobre rady starszych. Coraz bardziej przekształca się w planowy proces, w świadomą działalność organizowania warunków sprzyjających rozwojowi pokolenia dzieci” (tamże, s. 13). Pytanie o jakość łączy się z problemem poprawy warunków rozwoju małych dzieci, zwłaszcza ze środowisk zaniedbanych społecznie i ekonomicznie. W związku z tym kluczowa wydaje się odpowiedź na pytanie: Jakie wskaźniki jakości są najbardziej znaczące w sensie rozwojowym? (tamże, s. 16). Rozwój małych dzieci jest bardzo zróżnicowany, a placówki na całym świecie cechuje również różnorodność podejścia i jakości proponowanych usług. Źródłem tego jest odmienność spojrzeń na procesy rozwojowe i wychowania, różnorodność środowisk wychowawczych, systemów, inna kultura, obyczajowość, tradycje, wartości wychowania w rodzinie, metody kształcenia, inna organizacja placówek, inne potrzeby środowiska (tamże, s. 116). Jakość wiąże się z perspektywą uwzględnienia odpowiednich nakładów finansowych na poprawę funkcjonowania placówek dla najmłodszych dzieci. Dziś wiele krajów boryka się z tym, jak obniżyć nakłady przy zachowa- 
niu dobrej jakości opieki i edukacji małych dzieci. Wysokość nakładów zależy zatem od zamożności krajów i społeczeństw. „Kluczowym problemem jest to, czy jest rzeczą możliwą, a nawet pożądaną, ustalenie minimalnych standardów nakładów koniecznych dla zaspokojenia potrzeb dzieci”" (tamże, s. 20). W Stanach Zjednoczonych obniżyła się znacznie jakość wczesnej opieki i edukacji. „Wysokiej jakości usługi dla małych dzieci występują tam rzadko, pogarszają się i są nierównomiernie rozproszone. Badania pokazuja, że jakość programów - czy to wdrażanych w placówkach, czy w domach - jest zwykle poniżej normy; w większości badanych placówek jakość oceniono jako złą lub mierną, a prawie połowa pomieszczeń stwarzała zagrożenie dla zdrowia i bezpieczeństwa dzieci. W większości badanych placówek zaobserwowano jedynie zwykłą opiekę nad dziećmi. Dzieci niemające dostępu do finansowania zapewnianego przez rząd lub przedsiębiorstwa i pochodzące z rodzin o niskim dochodzie, są szczególnie narażone na uczestnictwo w zajęciach niskiej jakości" (Kagan, Cohen, 1996, s. 3-4). Jednocześnie możemy zaobserwować, że rynek opieki nad dziećmi coraz bardziej przyciaga bogate firmy, prywatnych przedsiębiorców (pokazuje to także Raport Instytutu Key Note na temat opieki nad dziećmi w Wielkiej Brytanii) (Dahlberg, Moss, Pence, 2013, s. 122).

\section{Obszary jakości wczesnej opieki i edukacji}

Martin Woodhead badał zróżnicowanie jakości wczesnej opieki i edukacji w Wenezueli, Kenii, Indiach i Francji - opracował, raport, którego celem było sprecyzowanie ram dla dyskutowania pojęcia jakości, zbadanie możliwości opracowania wspólnych punktów odniesienia oraz zastosowanie tych ram dla lepszego zrozumienia kwestii jakości. Przy analizie okazało się, jak wiele czynników określa jakość. Woodhead zestawił etapy cyklu rozwoju jakości (Woodhead, 1998, s. 121-124):

- definicja ekologii rozwoju - jakie sa główne konteksty opieki/edukacji matych dzieci, jak sq stabilne, jak się zmieniaja?

- analiza zainteresowanych przedmiotów - kto jest zainteresowany placówkami, jaki interes maja te osoby w rozwijaniu potencjału małych dzieci?

- ocena różnorodnych perspektyw - jakie sq przekonania osób zainteresowanych, jakie maja wspólne poglady?

- kontekstowe podejście do wiedzy naukowej-jakie badania, teorie, modele i podejścia maja odniesienie do danej sytuacji, gdzie mieszcza się punkty wspólne? 
- ocena potencjalnych środków - jakie sq koszty $i$ zasoby $w$ programie $w$ sensie dóbr trwatych - budynki, sprzęt, wyposażenie, infrastruktura $i$ w sensie zasobów ludzkich, możliwości kształcenia?

- negocjowanie odpowiednich kontekstowo „potrzeb” i praktyk - jakie sq potrzeby dzieci $w$ kontekście doświadczeń nabywanych $w$ rodziniel społeczeństwie, jakie sq cele instytucji, liczebność grup, metodyka pracy $z$ dziećmi, zakres indywidualizacji, form wspótpracy z rodzicami?

- ocena podstawowych potrzeb i praw - czy program zaspokaja podstawowe potrzeby $w$ dziedzinie odżywania, ochrony zdrowia i bezpieczeństwa, jak można chronić dzieci przed niewłaściwym traktowaniem?

- określenie wskaźników jakości - jakie odpowiednie wskaźniki osiagnięć dzieci dotyczace zdrowia, przystosowania, uwzględniajace lokalne/kulturowe uwarunkowania moga być zidentyfikowane?

- wdrażanie systemu oceny - jakie niskonaktadowe systemy najlepiej będq na bieżaco sprawdzały jakość, poziom nakładów, proces $i$ wyniki, jak można je wdrożyć w danym kontekście lokalnym w sposób prosty, przydatny $i$ bez nadmiernej biurokracji?

- określenie dziedzin rozwoju i zmian - jak można najkorzystniej wdrożyć zmiany, jakie były reperkusje zmian dla szerszych aspektów systemu opieki, wychowania i edukacji?

Wskaźniki jakości odnoszące się do nakładów, procesu i wydajności, mogą być następujące (Woodhead, 1998, s. 48):

- wskaźniki nakładów - odzwierciedlają trwałe elementy instytucji: budynek i jego otoczenie, materiały i sprzęt, personel;

- wskaźniki procesu - pokazują, co w programie opiekuńczo-edukacyjnym faktycznie na co dzień się dzieje: styl opieki, doświadczenia dzieci, strategie nauczania i uczenia się, regulowanie zachowań społecznych/ dyscypliny, relacje między dorosłymi, relacje między rodzicami, opiekunami i innymi osobami;

- wskaźniki wydajności - wskazuje, jak instytucja oddziałuje na dzieci: zdrowie, umiejętności dzieci, przystosowanie dzieci do instytucji, podejście rodziny.

Współczesne przedszkola cyklicznie mierzą się z oceną jakości pracy. $\mathrm{W}$ jednym z zaprezentowanych raportów wymienia się następujące wskaźniki jakości pracy przedszkola, procesu i zarządzania (Dzierzgowska, M. Rościszewska-Woźniak, 2001):

- efekty pracy przedszkola: losy absolwentów, rozwój intelektualny, duchowy, moralny, kulturalny i społeczny dziecka, zadowolenie rodziców i nauczycieli, 
- przebieg procesu wychowania, nauczania i opieki w przedszkolu: organizacja pracy, rekrutacja do przedszkola, programy wychowawczo-dydaktyczne, innowacje i eksperymenty, wychowanie, atmosfera w przedszkolu, kontakty interpersonalne, frekwencja, imprezy, wycieczki, konkursy, opieka, wyżywienie, prawa dziecka, równość szans, współpraca $\mathrm{z}$ rodzicami i środowiskiem lokalnym,

- zarządzanie: dyrektor, dokumentacja przedszkola, planowanie pracy przedszkola podstawowe wskaźniki strukturalne, kierowanie zespołem ludzi (selekcja kandydatów, kryteria oceny nauczycieli, systemy motywacyjne, doskonalenie nauczycieli, rotacja pracowników), informacja i promocja, baza przedszkola (warunki pracy, ocena wyposażenia), finanse.

Obszary/wskaźniki jakości ustalano w toku badań ilościowych - ankietowych (przeprowadzono ankietę wśród rodziców nt. „Przedszkole mojego dziecka”, ankietę dla nauczycieli i personelu nt. „Przedszkole, w którym pracuję", „Systemy motywujące stosowane w przedszkolu”, „Doskonalenie zawodowe”).

\section{Wczesna opieka nad dzieckiem do lat trzech w Polsce}

Przyjrzyjmy się, jak przedstawia się obecna sytuacja wczesnej opieki dziecka do lat 3 w Polsce i w Europie w kontekście wskaźników jakości usług, regulacji prawnych, norm rozwojowych dziecka.

W Polsce nie przywiązywało się dotąd wystarczającej wagi do wspierania wczesnego rozwoju dzieci, co potwierdzają najniższe w Unii Europejskiej statystyki. Żłobki (jedyna dotychczasowa forma opieki dla małych dzieci) funkcjonowały jako zakłady opieki zdrowotnej i musiały spełniać wymogi higieniczno-sanitarne. By zmienić tę sytuację, w lutym 2011 r. Parlament RP przegłosował Ustawę o opiece nad dzieckiem $w$ wieku do lat 3. To pierwsza taka ustawa w Polsce, która poświęcona jest usługom dla najmłodszych dzieci. Żłobki przestały być instytucją systemu zdrowia, a stały się elementem polityki społecznej - nadzór nad nimi przeszedł z Ministerstwa Zdrowia do Ministerstwa Pracy i Polityki Społecznej. Liczba żłobków w Polsce jest zdecydowanie zbyt mała, gdyż daje szansę korzystania z ich usług tylko około 3,0\% populacji dzieci w wieku 0-3 lata w miastach i znikomemu odsetkowi populacji dzieci na wsi. Według danych GUS liczba dzieci w wieku 0-3 lata w Polsce w 2011 r. wynosiła 1668293 (Dzieci w Polsce, 2013. Raport). Sytuację, tylko w niewielkim stopniu, poprawiło wprowadzenie nowych form opieki nad dziećmi w wieku żłobkowym. W całej Polsce w 2011 r. było tylko 581 żłobków. Powsta- 
łe po 2010 r. kluby dziecięce zwiększyły tylko w nieznacznym stopniu liczbę dostępnych miejsc opieki dla dzieci do lat 3. Placówki opieki nad dziećmi do lat $3 \mathrm{w}$ Polsce ( $\operatorname{stan} \mathrm{w}$ dniu 31.12.2011 r.) wg danych GUS przedstawiają się następująco: żłobki 49,9\%, oddziały żłobkowe 12,9\%, kluby dziecięce 12,9\%, inne formy $24,3 \%$. Mimo iż pojawiło się dość dużo nowych placówek, to jednak zazwyczaj dysponują one niewielką liczbą miejsc (16-17) oraz w większości mają charakter niepubliczny. „Sytuacja taka skutkuje zarówno brakiem miejsc w żłobkach, wydłużonym okresem oczekiwania na przyjęcie dziecka, jak i przepełnieniem placówek. Dostęp do opieki nad dziećmi i edukacji prezentuje się znacznie lepiej w przypadku przedszkoli niż w przypadku żłobków, gdyż współczynnik skolaryzacji, systematycznie rosnący od roku 2005, wyniósł w roku szkolnym 2010/2011 69,9\%. Jednak, gdy weźmiemy pod uwagę miejsce zamieszkania, to okazuje się, że w miastach do przedszkoli uczęszcza zdecydowanie więcej dzieci niż na obszarach wiejskich, a dysproporcja ta, mimo ogólnego wzrostu wskaźnika, jest nadal znacząca (w roku szkolnym 2010/2011 wskaźnik skolaryzacji wynosił $83,6 \%$ w mieście i $51,2 \%$ na wsi). Sytuację na obszarach wiejskich tylko w niewielkim stopniu ratują istniejące przy szkołach podstawowych oddziały przedszkolne oraz zespoły i punkty przedszkolne. $\mathrm{Na}$ terenach wiejskich praktycznie nie istnieje instytucjonalna opieka nad dziećmi do lat 3 (miasto 99,5\%, wieś 0,5\% - procentowy udział żłobków i oddziałów żłobkowych przy przedszkolach w miastach i na obszarach wiejskich w Polsce w 2011 r.)" ( Dzieci w Polsce 2013. Raport).

Tabela 1. Informacja na temat żłobków i klubów dziecięcych znajdujących się w rejestrze żłobków i klubów dziecięcych na dzień 31 grudnia 2012

\begin{tabular}{|l|c|c|c|c|}
\hline Wyszczególnienie & Żłobki & Kluby dziecięce & Dzienny opiekun & Razem \\
\hline $\begin{array}{l}\text { Liczba gmin, } \\
\text { w których } \\
\text { funkcjonują } \\
\text { instytucje }\end{array}$ & 295 & 85 & 8 & 388 \\
\hline Liczba instytucji & 791 & 105 & 30 & 926 \\
\hline $\begin{array}{l}\text { Liczba dzieci } \\
\text { w instytucjach }\end{array}$ & 38668 & 527 & 79 & 39274 \\
\hline
\end{tabular}

Źródło: wg danych GUS 2012.

Zgodnie z Ustawa z dnia 4 lutego 2011 roku o opiece nad dziećmi w wieku do lat 3 (Dz. U. 2011, Nr 45, poz. 235) żłobek jest jedną z kilku form opieki nad małymi dziećmi (do 3 r.ż.), których celem jest pomoc rodzicom w godzeniu pracy zawodowej z obowiązkami rodzinnymi (opieką nad dziećmi). Ma wspie- 
rać rodziców w opiece i wychowaniu dzieci, ale przede wszystkim zapewniać dziecku możliwość uczenia się przez zabawę oraz opiekę w czasie, gdy rodzice nie mogą jej sprawować osobiście, np. w czasie, gdy są w pracy. Co ważne, żłobek zapewnia dzieciom opiekę w warunkach jak najbardziej zbliżonych do warunków domowych, a więc ma w nim być bezpiecznie i przytulnie. Dzięki temu dziecko może czuć się komfortowo, a odpowiednio przygotowana kadra pomoże mu się szybciej rozwijać - zdobywa nowe umiejętności społeczne, takie jak praca w grupie, nawiązywanie relacji z innymi dziećmi, ale także uczy się samodzielnej zabawy. W żłobku opieka sprawowana nad dziećmi przez opiekuna odbywa się do dziesięciu godzin dziennie względem każdego dziecka. Jeżeli zachodzi uzasadniona konieczność, czas pozostawania dziecka w żłobku może zostać wydłużony za dodatkowa opłatą. Jeden opiekun w żłobku może sprawować opiekę nad maksymalnie ośmiorgiem dzieci, a w przypadku gdy w grupie znajduje się dziecko niepełnosprawne, dziecko wymagające szczególnej opieki lub dziecko, które nie ukończyło pierwszego roku życia maksymalnie nad pięciorgiem dzieci. Do żłobka mogą uczęszczać dzieci w wieku od ukończenia 20 tygodnia życia do lat 3, w wyjątkowych sytuacjach do lat 4 .

Klub dziecięcy jest jedną z form opieki nad małymi dziećmi, których celem jest pomoc rodzicom $\mathrm{w}$ godzeniu pracy zawodowej z obowiązkami rodzinnymi (opieką nad dziećmi). Ma wspierać rodziców w opiece i wychowaniu dzieci, ale przede wszystkim zapewniać dziecku możliwość uczenia się przez zabawę oraz opiekę w czasie, gdy rodzice nie mogą jej sprawować osobiście, np. w czasie, gdy są w pracy. Co ważne, klub dziecięcy zapewnia dzieciom opiekę w warunkach zbliżonych do warunków domowych. Dzięki temu dziecko czuje się bezpiecznie, a odpowiednio przygotowana kadra pomoże mu się szybciej rozwijać - zdobywa nowe umiejętności społeczne, takie jak praca $\mathrm{w}$ grupie, nawiązywanie relacji $\mathrm{z}$ innymi dziećmi, ale także uczy się samodzielnej zabawy. W klubie dziecięcym opieka sprawowana nad dziećmi przez opiekuna odbywa się do pięciu godzin dziennie względem każdego dziecka. Jeden opiekun w klubie dziecięcym może sprawować opiekę - nad maksymalnie ośmiorgiem dzieci, a w przypadku gdy w grupie znajduje się dziecko niepełnosprawne, dziecko wymagające szczególnej opieki maksymalnie nad pięciorgiem dzieci. Do klubu dziecięcego mogą uczęszczać dzieci w wieku od ukończenia pierwszego roku życia do lat 3 , w wyjątkowych sytuacjach do lat 4 . Opiekunem w żłobku i klubie dziecięcym może być osoba posiadająca kwalifikacje: pielęgniarki, położnej, opiekunki dziecięcej, nauczyciela wychowania przedszkolnego, nauczyciela edukacji wczesnoszkolnej lub pedagoga opiekuńczo-wychowawczego. Ponadto opieku- 
nem może być także osoba, która posiada co najmniej wykształcenie średnie oraz co najmniej dwuletnie doświadczenie w pracy z dziećmi w wieku do 3 lat lub przed zatrudnieniem jako opiekun w żłobku lub w klubie dziecięcym odbyła 280 -godzinne szkolenie, z czego co najmniej 80 godzin w formie zajęć praktycznych, polegających na sprawowaniu opieki nad dzieckiem pod kierunkiem w pełni wykwalifikowanego opiekuna. Jeżeli osoba, która posiada co najmniej dwuletnie doświadczenie $\mathrm{w}$ pracy $\mathrm{z}$ dziećmi w wieku do 3 lat oraz średnie wykształcenie, ale nie pracowała $\mathrm{z}$ dziećmi w wieku do 3 lat przez okres co najmniej 6 miesięcy bezpośrednio przed podjęciem zatrudnienia jako opiekun, zobowiązana jest w ciągu 6 miesięcy od rozpoczęcia pracy na stanowisku opiekuna odbyć 80-godzinne szkolenie w celu uaktualnienia i uzupełnienia wiedzy oraz umiejętności. Przy zapewnianiu opieki nad dziećmi przebywającymi w klubie dziecięcym można korzystać z pomocy wolontariuszy. Wolontariusz, przed rozpoczęciem świadczenia pracy w klubie dziecięcym, zobowiązany jest odbyć 40-godzinne szkolenie (Dz. U. 2011, Nr 45, poz. 235). Zarówno opiekun w żłobku lub klubie dziecięcym, jak i wolontariusz są obowiązani, na podstawie ustawy o opiece nad dziećmi w wieku do lat 3, do poddania się obowiązkowym badaniom sanitarno-epidemiologicznym zgodnie z ustawą z dnia 5 grudnia 2008 r. o zapobieganiu oraz zwalczaniu zakażeń i chorób zakaźnych u ludzi.

Przyzakładowy klub dziecięcy - Ustawa z dnia 4 marca 1994 r. o zakładowym funduszu świadczeń socjalnych (Dz. U. 1996, Nr 70, poz. 335, z późn. zm.) daje możliwość utworzenia przez pracodawcę dla własnych pracowników, klubu dziecięcego.

\section{Wsparcie inicjatyw w zakresie wczesnej opieki nad dzieckiem}

Państwo od kilku lat wspiera inicjatywy instytucjonalne w zakresie opieki dla dzieci do lat 3. Minister pracy i polityki społecznej ogłosił m.in. Resortowy program rozwoju instytucji opieki nad dziećmi $w$ wieku do lat 3 „,MALUCH 2013" oraz Program Operacyjny Kapitał Ludzki 2007-2013 ze środkami unijnymi. Departament Wdrażania Europejskiego Funduszu Społecznego w Ministerstwie Pracy i Polityki Społecznej, zgodnie z założeniami Planu Działania dla Priorytetu I Programu Operacyjnego Kapitał Ludzki „,Zatrudnienie i integracja społeczna" na 2012 r., ogłosił konkurs zamknięty w Działaniu 1.5 PO KL Wspieranie rozwiqzań na rzecz godzenia życia zawodowego i rodzinnego -1 . Wdrażanie i upowszechnianie rozwiązań służących godzeniu życia zawodowego i rodzinnego oraz wspierających powrót do pracy po przerwie związanej z urodzeniem i wychowaniem dzieci, poprzez: wsparcie tworzenia i funkcjo- 
nowania żłobków i klubów dziecięcych, w tym pokrycie kosztów opieki nad dzieckiem w wieku do lat $3 \mathrm{w}$ żłobku lub klubie dziecięcym, w przypadku, gdy co najmniej jedno z rodziców lub opiekunów prawnych dziecka objętego opieką powraca na rynek pracy po przerwie związanej z urodzeniem lub wychowaniem dzieci; wsparcie usług świadczonych przez dziennego opiekuna. Inny wieloletni program Pomoc państwa w zakresie dożywiania również dla dzieci w żłobkach - dyrektor żłobka może przygotować listę dzieci wymagających pomocy w formie posiłku i przekazać ją do właściwego ośrodka pomocy społecznej, w celu przyznania pomocy. Kolejną ofertą skierowaną na wczesną opiekę są dotacje dla mikro, małych i średnich przedsiębiorstw w formie żłobka, klubu dziecięcego lub dziennego opiekuna - w ramach Działania 6.4 wspierane będą projekty dotyczące budowy, przebudowy, rozbudowy i modernizacji obiektów infrastruktury opieki nad dziećmi do lat 3 i/lub zakupu wyposażenia obiektów.

\section{Standardy jakości opieki i edukacji dzieci do lat 3}

Autorzy propozycji zmian określają, ,że nowy zawód (dzienny opiekun), jaki tworzy Ustawa, powinien mieć wysoką rangę społeczną i status zawodowy, ponieważ od jakości pracy opiekunek i opiekunów zależy jakość następnych pokoleń. Osoby zajmujące się opieka, wychowaniem i edukacją najmłodszych dzieci powinny być nazywane ,wychowawcami małych dzieci” (Rościszewska-Woźniak, 2012).

Na podstawie analizy funkcjonowania placówek dla najmłodszych dzieci, wskazuje się następujące obszary jakości standardów:

1. Przestrzeń dla dzieci do zabawy i wypoczynku.

2. Przestrzeganie praw dziecka.

3. Profilaktyka zdrowia dzieci i zapobieganie wypadkom.

4. Współpraca z rodzicami, opiekunami i rodzinami dzieci.

5. Adaptacja dzieci i przejście z grupy młodszej do starszej.

6. Sytuacje codzienne (powitanie, pożegnanie, posiłki, odpoczynek, toaleta).

7. Zabawa dzieci (warunki do zabaw, planowanie i dokumentowanie).

8. Kompetencje opiekunek i opiekunów.

Wyznacznikiem wskazanych obszarów jest założenie, że opieka nad dziećmi w wieku od 6 miesięcy do 3 lat powinna być zorganizowana w najlepszym interesie dziecka (Rościszewska-Woźniak, 2012)1.

\footnotetext{
${ }^{1}$ Standardy opierają się na Rozporządzeniu Ministra Pracy i Polityki Społecznej w sprawie
} 


\section{Wczesna opieka i edukacja nad dzieckiem do lat trzech w Europie}

Programy Organizacji Współpracy Gospodarczej i Rozwoju (OECD) pt. Starting Strong (statystyki dostępu do wczesnej opieki i edukacji) oraz Family Database (statystyki dotyczące rodzin) pokazują, że do żłobków i przedszkoli uczęszcza dziś większy odsetek dzieci niż kiedykolwiek wcześniej, a towarzyszy temu wzrost świadomości, iż korzystanie od najmłodszych lat z wysokiej jakości usług może znacząco się przyczynić do wyrównywania różnic. Coraz lepiej też rozumiemy, co stanowi o wysokiej jakości. Niemniej poziom usług dla dzieci do lat 3 jest wciąż niższy niż dla przedszkolaków. $Z$ analizy stopnia realizacji przyjętych w Barcelonie w 2002 r. założeń, które dotyczą zapewnienia miejsc w placówkach dla co najmniej 33\% dzieci w wieku do lat 3 wynika, że zakładany cel nadal nie został we wszystkich krajach osiągnięty - co więcej, nadesłane dane o dostępności usług należy traktować z dużą ostrożnością (Korintus, 2011). Systemy opieki różnią się w zależności od kraju - w rezultacie odmienne są definicje pojęć, treści nauczania i metody pedagogiczne. Bez uwzględnienia liczby godzin spędzonych w placówce, statystyki dostępności maskują istotne różnice, np. z danych ogólnych wynika, że z usług dla najmłodszych korzysta 45\% dzieci w Holandii i 33\% dzieci w Wielkiej Brytanii, ale tylko $4 \%$ dzieci holenderskich i 5\% dzieci brytyjskich uczęszcza do placówek przez co najmniej 30 godzin tygodniowo (tamże). Dla odmiany w Danii znakomita większość dzieci przebywa w placówkach przez cały dzień. Długo można by wymieniać przyczyny, dla których z opieki żłobkowej korzysta niewielki odsetek dzieci do lat 3 . Jedna z nich to dość nikłe zainteresowanie tą grupą wiekową w programach polityki społecznej. Przekonanie, że małe dziecko najlepiej wychowa się w domu jest nadal rozpowszechnione w wielu krajach, a najbardziej tam, gdzie miejsc w żłobkach brakuje. Dodatkowo do braku zainteresowania usługami dla najmłodszych przyczyniają się długie urlopy wychowawcze, np. na Węgrzech czy w Czechach. Dobrze płatny urlop trwa od zaledwie 1,5 miesiąca w Wielkiej Brytanii do 24 miesięcy na Węgrzech. Oprócz Węgier jeszcze dziewięć krajów (pięć nordyckich, Chorwacja, Estonia, Niemcy i Słowenia) oraz Grecja (dla pracowników sektora publicznego) zapewnia co najmniej 9 miesięcy dobrze płatnego urlopu. Reszta oferuje maksymalnie

wymagań lokalowych i sanitarnych dotyczqcych żłobków i klubów dziecięcych, Dz. U. , Nr 69, poz. 367, oraz Rozporzqdzeniu Ministra Pracy i Polityki Społecznej z dnia 25 marca 2011 r. w sprawie zakresu programów szkoleń dla opiekuna w żłobku lub klubie dziecięcym, wolontariusza oraz dziennego opiekuna, Dz. U., Nr 69, poz. 368. 
6 miesięcy. W tej grupie państw długość urlopu w zasadzie zależy od sytuacji rodziców, którzy co najwyżej mogą otrzymać bezpłatny lub nisko płatny urlop wychowawczy (Moss, 2011).

W Szwecji większość rodziców, którzy mają małe dzieci, pracuje albo jeszcze się uczy, dlatego prawie wszystkie maluchy w wieku od $1 \frac{1}{2}$ roku do 2 lat codziennie chodzą do żłobka, gdzie bawią się z rówieśnikami. Pobyt w żłobku jest dla szwedzkich dzieci doświadczeniem całkowicie naturalnym i powszechnie uznawanym za pozytywne. Ogólnoszwedzki program wychowania dla tej grupy wiekowej nazywa podopiecznych uczniami, a żłobek traktuje jako pierwszy szczebel systemu oświaty. W żłobku dzieci poznają siebie, innych ludzi oraz świat zewnętrzny. Takie podejście do pedagogiki zyskało ostatnio popularność jako ważne dla jakości usług. Od kilkunastu lat w Skandynawii realizuje się wiele prac badawczych dotyczących rozwoju dzieci przed ukończeniem 3 roku życia (Hansen, 2011).

$\mathrm{Z}$ uzyskanych danych płynie jasny wniosek: usługi dla grupy wiekowej 0-3 lat mogą przynieść ogromne korzyści rozwojowe pod warunkiem, że są odpowiedniej jakości. Wysoka jakość usług przekłada się na lepszą samoocenę, większą ciekawość świata oraz silniejszą motywację do nauki u podopiecznych, co w konsekwencji dodatnio wpływa na ich rozwój społeczno-intelektualny.

Badania prowadzone w dziewięciu duńskich żłobkach pokazały jednak, że mimo wielu podobieństw poszczególne placówki znacząco różniły się między sobą pod względem jakości pracy. Dobre żłobki zatrudniały lepiej wykształconych opiekunów, którzy umieli stworzyć więzi emocjonalne z dziećmi i zapewnić im poczucie bezpieczeństwa. Ponad 50\% kadry pracującej w Danii z najmłodszą grupą wiekową stanowią wysoko wykwalifikowani pedagodzy z wykształceniem uniwersyteckim. Każdy pedagog pracujący w żłobku ma pod swoją opieką nie więcej niż troje dzieci poniżej 2 roku życia, lub czworo dzieci w wieku 2-3 lat. Słabsze placówki nie dysponują wykształconą kadra, mają ograniczone środki finansowe i bywa, że działają w trudnym środowisku społecznym. Jeśli nie potrafią zastosować odpowiednich metod pedagogicznych, to nie pomogą swoim podopiecznym w rozwoju tak skutecznie, jak ośrodki dobre, choć $\mathrm{z}$ badań prowadzonych $\mathrm{w}$ krajach skandynawskich i anglojęzycznych wynika, że dla dzieci zaniedbanych nawet słaba placówka jest lepsza niż żadna (Hansen, 2011).

Duńskie formy opieki nad dzieckiem do lat 3 przedstawiają się następująco:

Żłobki - przyjmują dzieci, które ukończyły 26 tygodni; w grupie 0-3 lat korzysta $\mathrm{z}$ tej formy $99 \%$ dzieci. 
Przedszkola - przyjmują dzieci w wieku 3-6 lat; korzysta z nich zaledwie 3\% dzieci.

Ośrodki zintegrowane - dla dzieci w wieku od 3 miesięcy do 6 lat; korzysta z nich $40 \%$ dzieci w grupie $0-3$ lat.

Samorzadowe placówki opieki dziennej - dla dzieci od 26 tygodnia życia do 3 lat, opiekunowie dzienni organizują je we własnych domach dla grupy 4-5 dzieci; korzysta z tego 48\% dzieci w wieku 0-3 lat.

W roku 2004 wprowadzono w Danii podstawę programową pracy pedagogicznej dla wszystkich form wczesnej opieki i edukacji, a w roku 2007 włączono ją do ustawy o opiece dziennej nad małymi dziećmi (Dagtilbudsloven), która jasno określiła obowiązki władz samorządowych oraz cele systemu. Program dla dzieci w wieku 0-2 lat różni się od programu dla dzieci od 3 lat do wieku obowiązku szkolnego i proponuje zróżnicowane zajęcia, w zależności od poziomu rozwojowego podopiecznych. Dla opiekunów dziennych istnieją odrębne założenia programowe, różniące się od założeń przyjętych dla żłobków i ośrodków zintegrowanych. Podstawa programowa obejmuje sześć obszarów: wszechstronny rozwój osobowy, kompetencje społeczne, rozwój językowy, ciało i ruch, przyrodę i zjawiska przyrodnicze, wartości kulturalne i ekspresja twórcza (Lund, 2011).

W Finlandii system wczesnej opieki i edukacji ma charakter kompleksowy i zintegrowany (łączy się cele edukacyjne i opiekuńcze). Nadzór nad placówkami ma Ministerstwo Spraw Socjalnych i Zdrowia, ale nad zerówkami dla sześciolatków Ministerstwo Edukacji i Kultury. Opieka zinstytucjonalizowana obejmuje w Finlandii ok. 42\% dzieci w wieku 1-2 lat, a placówki publiczne stanowią ok. 95\% ogółu placówek. Fiński system oferuje jednakowe usługi dla wszystkich dzieci poniżej wieku szkolnego. Gminy prowadzą żłobki, przedszkola oraz rodzinne ośrodki opieki dziennej. Żłobki i przedszkola - przyjmują ok. 20-100 dzieci w wieku 1-6 lat; w żłobku na jednego opiekuna przypada 4 dzieci, a w przedszkolu 7 dzieci. 30\% kadry w żłobku i przedszkolu ma wykształcenie licencjackie z zakresu wczesnej pedagogiki i rozwoju wczesnodziecięcego. Rodzinne ośrodki opieki dziennej - najczęściej zakładane są w domach prywatnych (grupa liczy czworo dzieci), są popularne dla dzieci poniżej 3 lat z uwagi na domowe otoczenie. Opiekunowie przechodzą szkolenie zawodowe, poziom przygotowania opiekunów dziennych określa samorząd (Lund, 2011). 


\section{Podsumowanie i wnioski}

W obszarze wczesnej opieki i wychowania, w zakresie świadczonych usług wychowawczych i edukacyjnych, jakości działań, dostępności do placówek, ich upowszechnienia, wydłużania czasu pracy oraz wyrównywania szans rozwojowych i edukacyjnych jest jeszcze sporo do zrobienia - zmodyfikowania, ulepszenia, jednakże działania podejmowane przez państwa Europy od kilku lat przynoszą wymierne, zauważalne korzyści. Jest to kolejny etap niekończącego się procesu. W Polsce zintensyfikowane działania obserwujemy od czasu, kiedy rok szkolny 2008/2009 ogłoszono Rokiem Przedszkolaka - poprawiła się infrastruktura przedszkoli, dostępność do placówek, a wydatki na poprawę jakości pracy placówek przedszkolnych stały się dla wielu samorządów i gmin priorytetem. Stworzenie szans dostępności do placówek świadczących usługi dla najmłodszych dzieci na najwyższym poziomie staje się wyrazem troski w podejmowaniu konkretnych działań wielu podmiotów. W zintegrowanym, systemowym podejściu ogromne szanse mają dzieci z rodzin i środowisk o niskim kapitale socjokulturowym. Efektem wcześniejszego wyrównywania szans rozwojowych wśród najmłodszych dzieci są zauważalne już na poziomie edukacji wczesnoszkolnej rezultaty uczenia się i społecznego funkcjonowania.

Kluczowe pytanie dotyczy jakości (określania jej ram) wczesnej opieki i edukacji. Czym jest owa jakość, czy można wypracować i przyjąć jeden model w obszarze standardów jakości pracy z najmłodszymi dziećmi? Jak mierzyć jakość, jakie programy należałoby przyjąć, jak ocenić jakość usług?

„W kontekście różnic $\mathrm{w}$ jakości oraz dostępności usług (w krajach europejskich), należy uwzględnić wiele czynników, należy kulturowo spojrzeć na te różnice, na tradycje wychowania oraz opieki nad dzieckiem w danym kraju, inne resorty, inne nakłady, inny poziom świadomej współpracy z rodzicami, inna autonomia placówek, inne zasady finansowania, inne kwalifikacje, potrzeby i poziom zatrudnienia, inna polityka zatrudnieniowa, zwłaszcza kobiet, inny poziom społeczny i ekonomiczny oraz stopień ubóstwa" (Lund, 2011).

Jak stwierdzono w tekście, jakość postrzegana jest jako doskonałość, a dążenie do osiagnięcia wysokiej jakości to planowy proces i świadome działania wielu podmiotów. Wyznacznikiem jakości jest systemowe, zintegrowane podejście - wychowanie żłobkowe i przedszkolne; opieka, wychowanie i edukacja jako całość oddziaływań i najwyższej jakości usług. Niezbędne jest ustalenie klarownych zasad finansowania placówek i odpowiedzialności resortów, gmin, samorządów, prywatnych podmiotów oraz powszechny, rów- 
ny dostęp do placówek wysokiej jakości. Łączy się to z profesjonalizacją wykształcenia, kompetencjami i statusem opiekuna - nauczyciela/wychowawcy małych dzieci.

\section{Bibliografia}

Dahlberg G., Moss P., Pence A. (2013), Poza dyskursem jakości w instytucjach wczesnej edukacji i opieki. Języki oceny, Wrocław.

Dzieci w Polsce 2013 - dane liczby, statystyki (część dotyczaca żłobków i przedszkoli) (2013), Unicef, Warszawa.

Dzierzgowska I., M. Rościszewska-Woźniak (2001), Mierzenie jakości pracy przedszkola, Raport CODN, Warszawa.

Hansen O. H. (2011), O czym świadczq badania nad ustugami dla dzieci do lat trzech, „Dzieci w Europie", nr 20 (8).

Kagan S., Cohen N. (red.) (1996), Reinventing Early Care and Education: A Vision for a Quality System, San Francisco.

Komunikat Komisji Europejskiej (2011), Wczesna edukacja i opieka nad dzieckiem: zagwarantujmy wszystkim dzieciom w UE dobry start w przyszłość, Bruksela.

Korintus M. (2011), Jakie warunki rozwoju maja w Europie dzieci do lat trzech i co najlepiej stuży ich dobru, „Dzieci w Europie”, nr 20 (8).

Lund S. (2011), Ustugi wczesnej edukacji i opieki nad dziećmi do lat trzech w Danii, „Dzieci w Europie", nr 20 (8).

Mizerek H. (2012), Jakość edukacji. Dyskursy, które wybrzmiały, milczqc, [w:] Jakość edukacji. Różnorodne perspektywy, pod red. G. Mazurkiewicza, Kraków.

Moss P. (2011), Równowaga między życiem prywatnym a zawodowym Urlopy dla rodziców dzieci do lat trzech, „Dzieci w Europie”, nr 20 (8).

Raport (2011), Raport z realizacji projektu ECEC (Early Childhood Education and Care) Working for Inclusion, analizowany przez Fundację Rozwoju Dzieci im. J. A. Komeńskiego 2011.

Rościszewska-Woźniak M. (2012), Standardy jakości opieki i wspierania rozwoju dzieci do lat trzech, Fundacja Rozwoju Dzieci im. J. A. Komeńskiego, Warszawa.

Ustawa z dnia 4 lutego 2011 roku o opiece nad dziećmi w wieku do lat 3, Dz .U. 2011, $\mathrm{Nr} 45$, poz. 235. 
METAANALIZY BADAŃ EDUKACYJNYCH

Ustawa z dnia 4 marca 1994 r. o zakładowym funduszu świadczeń socjalnych, Dz. U. z 1996 r., Nr 70, poz. 335, z późn. zm.

Woodhead M. (1998), Dązenie ku tęczy. Poszukiwanie standardów jakości edukacji, Warszawa.

Żytko M. (2012), Dzieci do 3 roku życia - opieka czy edukacja? Analiza z perspektywy rozwiazań europejskich, „Problemy Wczesnej Edukacji”, nr 4 (19). 